\title{
Limitations to Win-win-win in Global Labor Migration
}

\section{Acute emigration, migrant return and money remittances in developing country development}

\author{
ARNO TANNER, Ph.D. \\ Visiting Scholar/ Researcher/ Academy Researcher \\ Migration Policy Institute, Washington D.C./ Finnish Directorate of \\ Immigration/ University of Joensuu
}

\begin{abstract}
International migration of educated labor is an ever increasing phenomenon, which at best benefits the immigrant himself, the sending country and the receiving country alike. After an overview of such benefits, this article will focus on the limitations of international labor migration -induced benefits for the country of origin. Three aspects that might lessen the actual benefits of global migration of the educated for the sending country will be elaborated: the hazards of emigration from, of the lack of migrant return to and of money remittances to the developing sending country. When is emigration acutely hazardous for a small developing country, how often does migrant return occur, and what is the actual effect of money remittances? Finally, could such limitations to sending country benefits of international migration be eliminated or minimized through international cooperation?
\end{abstract}

Keywords: international migration, immigration, immigration policy, emigration, ethics, development, brain drain, remittances, poverty, stability, democracy, conflicts, international cooperation

\section{Introduction}

Global migration today is a massive phenomenon that continues to increase. According to a recent report by the UN, the total number of international migrants, i.e. those residing in a country other than where they were born, was 175 million in 2000, or about 3 percent of the world population. In absolute terms, this global number is about twice as large as it was in 1970, and exceeds the 1990 estimate by some 21 million (United Nations 2002). Global migration is also an increasingly south-north and east-west phenomenon, particularly consisting of labor migration of the educated from developing to such developed countries that are in need of labor force (OECD SOPEMI 2002). 
The baseline of this article is that such international, educated labor migration from the developing world to the developed world is at best a healthy and recommended "winwin-win" phenomenon, not only for the skilled individual but also for the developing sending country and the needy receiving country with an intelligent immigration policy alike. This contemporary discourse of migration-related benefits will be shortly focused in the beginning.

Still, several dimensions of today's international migration of the elites seem to diminish this "win-win-win" point of departure. It is to hypothesize that three strengthening trends of global migration of the skilled will all lessen the benefit share of the emigrant sending country. These aspects will be focused at more closely: a) a case of large flows of highly skilled immigrants with families from critical branches of a poor and small country to a developed country, in a short period of time, b) the actual probability of permanent return to a sending country and c) the occurrence, the continuity and the factual macroeconomic effects of money remittances to a sending country.

Finally, if these aspects prove as founded trends that will decrease the sending country benefits of international elite migration, a focus will be made at possible measures to eliminate or to prevent the presumed drawbacks resulting from these aspects. Would there be viable international measures to minimize the benefit limitations of global migration to the sending country, on international and state level? What can be done for the optimal good of the sending country?

\section{Optimal global labor migration has undoubted benefits}

There is plenty of recent academic evidence that international migration of the elites is basically a positive phenomenon, for the individual, for the developing sending country and for the receiving country with a well-thought immigration policy alike. Not allowing free migration is typically characteristic for a backward country without great future hopes - and staying in a country where an individual cannot put his or her skills in optimal use is similarly devastating. Also, such country in need of certain kind of labor force that cannot or is not willing to utilize the global supply, is likely to lose to the more open immigration countries.

What is more, not is only the contrary negative, but there is proven evidence that free, intelligent and calm global educated migration brings clear benefits for the migrating individual, the sending country and the receiving country alike. Prior to going to possible limitations, let us first comprehend the confirmed or at least little controversial benefits for the individual and the sending and receiving countries. 


\section{Why hinder individual success?}

Let us think about countries such as Cuba and North Korea, which, in contrary to facilitating free over border movement of people, do actually hinder achieving the benefits of migration, through emigrant penalties and return prohibitions. In addition to the human rights aspects, the networks and communications left established without free migration are partial reasons to why these countries remain backward and the general living standard low. As Migration Policy Institute researcher Kevin O’Neil argues, “....whether or not labor export constitutes 'real' economic development, widespread agreement exists that stopping migration is neither possible nor desirable. Public policy made in the name of economic development must first and foremost reflect this reality: that the basic units of migration, and the most important actors for development, are migrants themselves, not the state” (O’Neil 2003).

Not only is limiting individual emigration negative; there is evidence of individual immigrant success, if chosen based on the needs of the receiving country. Individual migrant success is indicated by the economists George Borjas and Barry Chiswick, who not only agree that the potential and actual migrants are usually the most motivated and talented individuals, but who through a significant contribution to the destination country succeed, better than the average majority worker (Borjas 2000, 325-328; Chiswick 2000, 61). Often on a global level, in spite of temporary or permanent loss of resources in the sending country, through successful labor migration both a) the global economic human input of the talented individuals increases, through better global utilization of the abilities of such educated individual, and b) in case of a foreigner-friendly destination country, the well-being of the individual and his family is likely to increase, through better career avenues, through higher salary, and later even through enterprising back in the sending country, with better international networks (Tanner 2003).

In spite of the risk of increasing global (human resources moving northbound and westbound) and local wealth gaps, and possibly resulting to temporary or permanent brain drain, one has to deliberately drop down from the global and interstate level, to focus at the benefits and drawbacks of global migration as a whole: In case of the migrant having the skills and education currently in need by a recruiting country, migrant success is likely to occur, if he or she is wisely chosen, by a policy that is able to integrate the migrant on the long term (Tanner 2003).

\section{Sending country benefits: Beyond poverty and overpopulation relief}

In addition to many emigrating individuals, even the sending country is often on the benefiting side. As U.N. Secretary General Kofi Annan has in 2003 stated, "Emigration relieves the pressures of overpopulation and unemployment, and in time endows sender countries with an educated Diaspora who often bring or send home new skills, 
products, ideas and knowledge” (e.g. Factiva/Reuters 21.11.2003). Still, in labor migration, as e.g. O'Neil righteously states, it is an oversimplification to argue that either poverty or overpopulation, in and of themselves, would typically cause migration. People do move for a variety of reasons, and their movements are facilitated by complex and enduring transnational social networks (O’Neil 2003), both as push factors in the sending country and as pull factors in the receiving country (as Zelinsky had it in 1971).

In addition to relieving overpopulation and unemployment of the highly skilled, educated global labor migration may benefit the sending country micro economy for example through return (e.g. India and Taiwan) and remittances (Sander 2003, 4); remittances today account for more money than all official development aid. Indeed, there is a massive potential for a further increase in remittances. For example according to the Indian economist Jagdish Bhagwati, the aggregate income of Indian-born residents in the United States is 10 percent of India's national income, even though such residents account for just 0.1 percent of the Indian population (Bhagwati 2003, 102).

Also, expatriate Diasporas, contacts and philanthropy are currently much researched, as drivers of further sending country benefit. According to O’Neil, the concepts of "political and social remittances" have entered the conversation in response to the recognition that migration promotes the exchange of ideas and practices as well as people and money (O'Neil 2003). It is to assume that as such valuable "political and social remittances," one could consider a freer flow of information about the developed aspects of the well-off, typically democratic society: For example human rights, gender equality, social welfare, progressive taxation and environmental awareness.

Even in today's world of information and communication, where next to any information is accessible in the nearest Internet point, and where any major part of the globe is reachable with airplane within less than 24 hours, increasing international migration is apt to make added value to such transfer of information, and particularly to that of general human wisdom. Staying for months or years in an environment different to one's original one may at best widen individual comprehension of the concepts "difference", "globalization" and "togetherness".

\section{A country in need of labor force benefits}

There is a lot of general and country-specific evidence that a well-off receiving country in labor need benefits from well-selected labor immigration, through immigration filling human resource scarcities (Tanner 2003), through immigration giving a boost in the host country economy (Borjas 2000, 325-327) and through immigration bringing in new ideas and networks. 
The basic prerequisite for success is a well-developed system that is able to find such immigrant candidates that not only are diligent and find work, speaking the right language, but who continuously succeed in the host country labor market, and who are on the long run able to integrate in the host society daily life. (Tanner 2003.)

Let us look at research on the benefits of labor immigration in Canada and New Zealand - both considered as having developed immigration policies for labor recruitment. Canadian researchers DeVoretz and Laryea have - based on a wide historical survey - argued that in Canada, until the late 1980's, studying the economic effects of migration was rare, simply because the positive economic effects have formerly been considered so self-evident (DeVoretz and Laryea 1999). In Canada, the search for economic benefits through immigration started actually as early as in 1930's, when immigration was considered a major tool for both populating the whole country for agriproduction, and for establishing a country-wide, functioning infrastructure. Prime Minister Mackenzie King went in 1947 even further, stating in a high-profile speech that Canada is an under-populated country, the economy of which was in desperate need of the activating stimulus of immigration (Hawkins 1991).

Even after the emergency of more research on the subject in Canada, wide consensus on the positive effects of immigration on the economy is there, alive and well in 2004. Economists David and Alan Green found out, that by year 1995, economic benefits of labor immigration have become so evident, that immigration was in the new 1995 immigration policy allowed merely on economic grounds, independent of whether the formerly most important determinants for successful labor immigration, namely the ones of social adaptation, where perfectly in order in the immigrant candidate's personal "portfolio". Immigration became thus an unconditioned synonym for economic growth (Green and Green 1996, 17).

A similar, solid and relatively grounded belief in the positive economic benefit of immigration is visible in New Zealand. Here, the process started later, though, namely in 1984, when Labor party got into power. Mercantilism was transferred to deregulation and market liberalism. As a part of the deliberate dogmatic change, immigration was considered to have a positive impact on labor markets, on all kinds of construction, on foreign investment to New Zealand and on activating domestic market. Indeed, economic benefits were soon so visible that even the rightist opposition joined the pro-immigration coalition.

According to a wide quantitative survey of the New Zealander economist Jacques Poot (Poot in Trlin and Spoonley 1992), the GDP-related indicators of economic success rose undoubtedly faster during high net immigration than during a lower one. Poot also found out that immigration has in New Zealand caused a dynamic process that increases 
investments, innovations and positive differentiation; the immigrants in New Zealand are apt to bring along such skills and know-how about production and marketing that positively influences total national production (Poot 1992, 29-43).

Although Canada and New Zealand do belong to the elite of immigration policy development, and they may thus be argued as not the most representative samples, it is evident that economic benefits are to be expected if basic factors of immigration success are present in the national immigration policy - such as a timely and punctual charting of domestic labor market needs, good domestic multicultural relations, and the sufficient language skills and integrative ability and willingness of the immigrant and his/her family (Tanner 2003).

\section{Labor emigration always has sending country effects}

The basis in now laid. Global migration of the elites may bring value added to all the three basic counterparts: the individual, the sending country and the destination country alike. Still, because of the presumably increasing amount of global migration of the capable elites, with families, that are wished to and wish to integrate, new, serious limitations to the win-win-win starting point are emerging. Consequently, three significant questions will call for further consideration and ethical pondering: First of all, what kind of problems may a small, developing sending country encounter, if a large amount of migrants permanently embark from such important country branches as $\mathrm{R} / \mathrm{D}$, education or health? Second, when, how often and how permanently does return actually happen, especially if immigrant integration of some level has already happened? Third, without a permanent and fruitful return to the sending country, how probable, how consistent and how beneficial are money remittances ultimately?

\section{Independent of return, temporary skilled emigration is an acute risk}

The world's very poorest do not migrate internationally proportionally as much as do the more educated (e.g. O'Neil 2003). In contrary, the recent global migration has increasingly consisted of the movement of people with secondary education; According to Carrington and Detragiache, a whole of 88 percent of the immigrants to the OECD has had a minimum of secondary education (Carrington and Detragiache 1998, 21-23). Hence, global labor migration is increasingly becoming a movement of the educated with their families, hardly escaping overpopulation, famine, natural disasters nor poverty, but simply looking for new avenues for career, nicer working environments and an awesome pay.

Why would it be problematic that particularly the occupational elite are on the move in today's world? Unless being a clear surplus, or without compensative measures, this elite may consequently create an acute vacuum - independent of a possible permanent brain drain - of the best driving force in the development and well-being of the sending 
country. This vacuum is presumably minor and more temporary for such giants as China and India, and a more permanent and occasionally life-threatening one in e.g. Sub-Saharan Africa. Let us look at empirical evidence on the acute threats of skilled labor emigration for developing African and Asian countries.

Particularly Africa is acutely losing its elite. For example in health sector of some African countries, a total of 12 percent of experts has left in 2003 alone (All Africa, 18.2.2004), accelerating the ill circle started already $30-40$ years ago: Already between 1960 and 1987, Peter Stalker estimates Africa to have lost 30 percent of its educated labor force (Stalker 1994). Africa has lost a third of its skilled professionals in recent decades and has had to replace them with 100,000 expatriates from the West at a cost of USD 4 billion a year, according to the Regional Industrial Review 2001 report (All Africa 18.2.2004). Such money directed at the acute survival is primarily used at the expense of any secondary needs of money, such as research or development. Consequently, as development may slow down or altogether halt, there is an increasing chance of the emigrant not coming back at all.

Although return and remittances may later materialize, for compensating some of the educational expenses of the sending country, there are acute emigration-related problems if the country is small and thus vulnerable, if the percent of educated emigration is 20 or over (Beine, Docquier and Rapoport 2003). In the following, looking at the African example, I argue that the problems are particularly deep if experts leave from some critical branches such as R/D, health or education. Deficits e.g. in the health sector in Africa are, according to local experts, likely to acutely cause a diminished performance, again leading to stagnating and declining services and there through to declining utilization of health services in general (All Africa 18.2.2004).

A stable, educated African middle class will, according to one of the major developers of the Internet and an African emigrant, Philip Emeagwali, ensure that political power is transferred "by bullets instead of by ballots". However, constant emigration of professionals with technical expertise, entrepreneurial, managerial and medical skills makes it difficult to create an African middle class. The remaining two-class system is a great African problem: “...a massive underclass that is largely unemployed and very poor, and a few very rich people that are mostly corrupt military and government officials...”. Restless international mobility of the educated people may thus give rise to instability, poor leadership and endemic corruption, making it easier for the military to overthrow a democratically elected government (Emeagwali).

Hence, if skilled emigration from Africa is large in number from critical branches, downright societal unrest and conflicts seem possible, independent of a possible later return. At least indirectly, heavy migration of the occupational elite may under 
appropriate circumstances be a partial cause for the acute African misery, particularly that of the Sub-Saharan Africa.

Looking more closely at vocational fields in particular African nations, already brain outflow for a year or two hazards the critical sectors of health and education in countries such as Ghana, Tanzania, Malawi and Zambia. For example from Malawi, a strong outflow of health personnel has lately occurred. It is according to Reidar Oderth (2002) not quite excluded that these people might come back. However, a later return may not be sufficient for the survival of this AIDS-torn country: The average life span in Malawi has due to AIDS fallen to 36 years, and in the near future, AIDS may further kill a half of today's educated elite, particularly from the sectors of education and health (PANA Daily Newswire 22.9.2003). As, however, a large proportion of doctors and nurses have already embarked for Great Britain, there will presumably be an acute shortage of health personnel in the near future. Who will then ward the patients and inform about safe sex against a further spread of AIDS?

Also in Asia, even the relatively temporary emigration of the highly skilled is seen as a direct and acute problem that slows down or even halts current development. In Pakistan, over 30 percent of agricultural researchers and experts have recently emigrated from the departments of Pakistani government dealing with agriproduction and environmental development (Asia Africa Intelligence Wire 16.2.2002). If we think about Pakistan as a low labor productivity country, with half of the labor force employed in agriculture (Regional Surveys of the World 2002, 1125), a constant 30 percent shortage in governmental expertise on agriculture development is likely to critically hamper decent economic growth and resulting better avenues for democratic stability, right now, independent of a possible return a couple of years later. A proper post-Musharraf democracy should be established today. Some years from now, upon a possible return of the elite, the right momentum for democracy may already be gone.

\section{Today's integration and sending country weakening lessen emigrant return}

In the above chapter, we looked at the acute challenges of excessive emigration, still not excluding the chance that the Tanzanian teacher or the Pakistani agriexpert may once return back home. As already brain outflow and the restless moving back and forth of the occupational elite is acutely risky for the developing country, it is to presume that altogether without return, such acute problems may become permanent. In this chapter focus is on such temporary emigration of the educated (brain outflow) that leads to a lack of return, there through turning to permanent emigration (brain drain). Let us consider two aspects that presumably decrease the propensity of return, namely optimal integration in the host country and sending country weakening due to emigration. Finally, these two aspects combined, could it be argued that optimal 
integration in the host country and minimal improvement at home interplaying, brain drain is ever more likely?

First, how well does good host country integration negatively correlate with propensity to return permanently? Recent research discloses that immigrants often wish to keep in the host country, if the determinants of positive integration are there: the job, the family, some social networking and a feeling of belonging to the host country. The economists Amalie Constant and Douglas Massey looked in 2002 at guest workers in Germany, and they found out that they only return home when they lose access to German jobs, have strong social and economic ties to the sending country and lack social, political or psychological ties to Germany. When practical integration is there, i.e. full-time work, family, a feeling of German identity and German citizenship, the probability of return is .00015 (Constant and Massey 2002).

It is possible that specifically the highly educated are more mobile than such general "guest worker category". Still, also the Italian economist Riccardo Faini (2003) has come to the conclusion that success in the host country, including good integration, makes return essentially less likely. In case of "positive selection” (i.e. labor immigrants chosen by their occupational and integrative potential) of immigrants to the host country in the first place, Faini found out that the few that return would be the least successful ones (Faini 2003, 9). There through one might also question the actual benefit of the return of the less successful to the sending country.

What makes this improbability of integrated and successful immigrants returning significant is that the major labor immigration countries, such as Canada, Australia and New Zealand, systematically do their best to find immigrants that do integrate and succeed. In the explicit point systems, the along-immigrating family, an already waiting job and the personal characteristics that contribute to optimal integration - such as language skills - are increasingly preferred (Tanner 2003). These are precisely the similar factors that Constant and Massey see as diminishing the chance of the guest worker returning home from Germany. Even in such high-profile labor immigrant countries as the United States, where the point system is not that transparent, similar factors of smooth integration are carefully focused.

As such "positive selection" is a natural prerequisite for a successful immigration policy, and as positive selection more easily leads to a better integration (Tanner 2003), which again leads to less chances for return, it can be argued that the more successful the immigration policy, the less are there chances for immigrant return, and, even in case of return, as Faini had it, the returnees are not the brightest ones, in large numbers, but the returnees are few and the ones that have not made it in the host country. 
Based on this logic, it seems that as concerns return, global labor migration is often a zero-sum game: The developed world in need of labor is creating immigration systems that find immigrants with "success" characteristics, and integrating these immigrants - both logical measures for long-term destination country success - seems to considerably lessen the probability of return.

Another, rather logical aspect that makes return to the original sending country ever more improbable today is that unless some economic or political progress has during the time abroad happened in the sending country, creating better avenues for career and well-being, return is improbable (Kwok and Leland 1982). A recent development, supporting Kwok and Leland, has been visible e.g. in Bangladesh in year 2001, where a large amount of returning emigrant scientists re-emigrated, as there were no jobs vacant in their academic fields, because of the shrinking of these fields, which, again, was in causality with heavy emigration (The Independent 17.7.2001).

In other words, emigration may weaken the country, feeding the vicious circle of lessening returns. According to Beine, Docquier and Rapoport (2003), brain drain has significant negative effects for a country, from which the percent of emigration is above 20. Such development has been visible in some branches in Sub-Saharan Africa, particularly concerning teachers and doctors from Nigeria, Ghana, Zambia, Tanzania and Malawi. Generally in Africa, according to Philip Emeagwali, the professionals that are emigrating out of Africa include those with technical expertise, entrepreneurial, managerial and medical skills. Such emigration leads e.g. to a severe lack of doctors, and consequently the poor are forced to seek medical treatment from traditional healers while the elite fly to London for their routine medical checkups. A shrinking and weakening medical sector is making return ever less lucrative (Emeagwali).

In sum, although there is as of yet no direct academic evidence on the causality between expert emigration, host country integration/sending country stagnation and the probability of return, the three following trends of contemporary international migration will further lessen return: First of all, immigration policies of today's developed countries with need of labor are more carefully searching for such people who are well educated and who can be integrated. The higher the education of the individual and the better the integration, the less are the chances for return. Second, partly resulting from the modern, integrative policies of e.g. Canada and New Zealand, the educated in the developing world are also increasingly responding to such invitation, taking the family along, and wishing to integrate. Third, due to a consequent increasing outflow and destination country integration of the educated, the larger are the chances for sending country suffering and economic stagnation. In case of African doctors, for example, a shrinking and weakening medical branch is making these countries ever less lucrative for expatriate return. 


\section{Brain drain relief? About the consistency and macro effects of remittances}

In case of acute loss of educated workforce, or even in case of altogether lacking returns, money remittances may acutely and on the long run compensate for some loss of the educated. Global monetary remittances to the sending country are a currently increasing, vast phenomenon. In 1999, the officially registered remittances to developing and former communist countries came to over 65 billion US\$ (Stalker 1994). In 2002, this amount had risen to 80 billion US\$, with estimates that unofficial flows included, the total amount might be between 100 and 200 billion US\$ (Sander 2003). In 2001, the total of officially transferred remittances was 40 percent higher than all official development aid (Obadina 2003). According to O'Neil, remittances have grown both in nominal terms and relative to source countries' GDPs, far outpacing growth in official development assistance (O’Neill 2003).

Nevertheless, remittances and the academic interest in them have grown while questions about how best to capture ideal development impact remain. However large the annual global remittances per se, there is mutually contradictory evidence about the individual consistency and the ultimate sending country benefits of remittances. Let us elaborate on four critical aspects. First of all, it is argued that individual remittances do essentially diminish over time, due to host country integration and citizenship (goals particularly pursued by today's developed countries in need of workforce). What is more, remittances are typically used ineffectively as concerns macro economy, to private daily consumption, to health expenses and to real estate maintenance and investment (e.g. Sander 2004). Actually, due to the increased liquidity of the ones receiving remittances, the prices within e.g. health sector may rise, there through decreasing parity. Based on the above, there is doubt whether remittances ultimately relieve poverty and income gaps on macro level. Finally, remittances in general may increase enterprising sluggishness and excessive international dependence in the sending country.

Let us first look at the continuity and consistency of remittances. Economists Lowell and De La Garza have in year 2000 surveyed the continuity of over border traffic of remittances between Mexico and the United States, one of the liveliest borders in the world as concerns migration. They have in wide quantitative studies found out, that although single individual remittances did increase over time, both the quantity of senders and the total of all remittances sent in a given time did actually decrease. A one percent increase in the period of stay in the United States diminished the probability to send remittances by 2 percent. Getting U.S. citizenship further lessened the chance for sending money back to Mexico. What is more, the better the education of the immigrant, the less probable it was that he/she was remitting; every extra year in education diminished the propensity to send money back by 7 percent. Even less probable was remitting, if the family had joined the immigrant (Lowell and De La Garza 2000, 18). 
Quite as was the case in return to the sending country, the contemporary trend in international migration - namely the global movement of the educated, families coming along, to a developed country which wants to have the educated immigrants permanently - include precisely such factors that also according to Lowell and De La Garza simultaneously diminish the probability to remit: family integration, permanent residence and high migrant education. An even stronger development is visible e.g. in Pakistan, from where net emigration has increased, but to which the total amount of remittances has downright decreased in recent years (Pakistan \& Gulf Economist 3.8.2003).

Another, equally important question is who and how do the remittances actually benefit as concerns the sending country. Two, interplaying factors are dealt with earlier in this article. As a) international migration is increasingly becoming migration of the elites and $b$ ) as remittances are basically used to personal expenses, health and real estate investments of the home-left families, it follows that a lot of remittances is used by and near the families of the elites, with only a limited amount of the money having to do with the general better performance of the whole macro economy. It should be questioned, how remittances would decrease income gaps and enhance the situation of the poor. Again, if income gaps rather widen than get narrower, this is on the long run apt to lead to a sharpening of the societal situation, rather than to development. Little research is as of yet out concerning this subject, though.

Third, how about the actual developmental effect of remittances? O’Neil presents the key issue: "There is debate that rather than promoting the structural changes needed for development, remittances may actually delay them while creating unsustainable local and family economies. This argument draws a parallel to natural resource windfalls and posits that migration's potential is squandered if it raises incomes without boosting human capital and institutional capacity. According to this line of thought, migration may rob developing countries of their most motivated and innovative people, delaying institutional change" (O’Neil 2003). The developing country receiving remittances may thus go on living in an illusion of development. Upon a sudden cessation of remittance flows, for any, yet unknown reason, the acute disclosure of such defective structures and the actual lack of human innovation might cause serious societal problems in the sending country concerned.

Finally, assets pouring from the outside may not only cause a false illusion of development, but they may also cause innovative sluggishness, excessive international dependency and increasing "materialism". In Africa, even the relatively developed countries such as Egypt and Morocco are highly dependent on remittances from Europe and Northern America. According to Glytsos, the collecting together of imported material, due to remittances, has caused backwardness in Egypt's own economy 
(Glytsos 2002, 19). A similar, quite recent worry is presented in the Philippines, to which overseas workers last year sent through official routes a record of 7.6 billion US\$, 6.3 percent more than in 2002 and accounting for 16 percent of current account receipts and 10 percent of the gross domestic product. According to Dr. Alburo, associate director of research in the University of the Philippines' economics department, "There is a reluctance to go for bold reforms that would essentially try to absorb more labor because there are huge foreign exchange inflows that cushion the government's balance of payments...” (South China Morning Post 17.2.2004).

Deducing from the above four aspects, remittances, despite massive in quantity and often positive in effect, are not an automate; their occurrence per individual decreases, they do not even up income disparities, they may create a false perception of real development and finally, they may actually cause excessive international dependence and innovative depression.

\section{Any hope visible?}

It is clear that in the former three chapters, the challenges of acute emigration, return and remittances for the sending country are looked at in a very critical fashion. In spite of the sceptical look at these factors, there is likely to be plenty of cases, where, ideally, merely the surplus of the educated leaves (often India and China), then either a) they stay in the host country for the minimum time sufficient for gathering sufficiently money, cumulating ideas and creating networks, and come back, to utilize the money, ideas and networks for the good of the repatriate himself and for the sending country alike or b) such migrants are left in the sending country for a longer time, still creating and maintaining networks, contacts and remittances to the sending country (Philippines).

Increasingly, however, such Alice-in-Wonderland-type story does not correspond with reality. Further research is needed, particularly about the sending country effects of emigration, about the propensity and benefits of return, and about the probability and positive developmental effects of remittances. For the author, many further question marks have emerged. Particularly the core ethical question for deeper future research, well presented e.g. by Richard Black (2003) concerning remittances, is the following: What consequences do the recruitive immigration policies of the developed world and the consequently strongly increasing international migration of the talented have on the societal problems of the developing world? The demanding scholar should inquire the ultimate consequences of international migration of the educated; Better career avenues in the developed world - without return and with lessening and badly poverty-lessening remittances - may finally lead to turmoil in the more vulnerable countries. In turmoils, the poorest have the least social and economic "buffers", and they therethrough tend to suffer most on the long run. 


\section{Future measures to increase the probability of win-win- win?}

Principally, the problems of brain drain, lack of return and diminishing remittances all can be controlled and minimized. As, however, global migration is an international phenomenon, with two or more mutually totally different state actors, with partly different national interests, added with other operative actors on all other levels of analysis (international, regional, local and particularly - individual), monitor, a comprehensive analysis, and at best, satisfactory control of these problems is only possible through a global framework. As, however, there are well-known problems in larger agreements and bodies such as the UN, WTO, the World Bank, EU and GATT, it is improbable that all the diverse and partially mutually exclusive interests of all levels could be agreed through international agreements, let alone in any next to utopianist consensus.

Reflected to this background, the recent initiatives following those of Howard Chang (Chang in Rudolph 1998) and Bimal Ghosh (see e.g. Ghosh 2000, 220-247), namely those of the Indian economist Jagdish Bhagawati, added with the "Berne Initiative" and the "World Commission of Migration" all are encouraging efforts to create international frameworks and forums to make international migration a globally inclusive rather than exclusive phenomenon. Let us have a short look on the three latter, most recent ones: Are they, and if yes, considering the acute problems, lacking returns and inconsistent as well as macro-economically scarcely useful remittances for the sending countries?

Jagdish Bhagawati presents in Foreign Affairs (Jan./Feb. 2003) two logical and significant arguments; First of all, as the right to migrate is a universal human right, global migration towards areas of better quality of life is inevitable and natural, and should thus not be synthetically halted. Second, as it is in today's world, return seems ever less probable. Therefore, an idea of internationally structured and managed immigrant "Diasporas" is established; to partly redistribute the immigrant-induced benefits for the host countries a tax for the sending country should be levied. (Bhagwati 2003, 98-104.)

Bhagwati's ideas are worth considering; the natural flows of people should not be forcefully halted, nor left drifting in a vacuum outside both the sending and the destination country. Taxes directly to the sending country government might decrease the probability of sluggishness and vague macroeconomic benefits. The establishment of Diasporas that would be systematically linked to the sending country might partly overcome the problem of over time decreasing contacts and remittances. On the challenging side might be the chance of developing country governments starting to create "emigrant industries" for maximum profit. In such pursuits, sending country $\mathrm{R} / \mathrm{D}$ and improvement might become secondary, in primary search for "emigrant revenues". 
Bhagwati's WMO should thus have strong powers and fair decision-making, to check that such taxes would be paid orderly. Further aspects for consideration: Which countries would join the organization, and how would the powers be dealt? Consensus in decision-making is an impossible option in today's world, so if the United States would join, would a United States-lead majority be fair for the smaller, occasionally disagreeing immigrant country, and would it be fair for all the sending, usually developing countries, and independent of contemporary foreign political streams? Also, the revenue flows should be evenly distributed, particularly to R/D of the sending countries. Who would have the ethical right and sufficient authority to monitor, guideline and, if necessary, control the governments in the sending countries? Another difficult question is how to make such taxes globally fair enough, and should one relatively or in absolute terms calculate the tax that should be paid: Paying one dollar to Finland is totally different from paying one dollar to Bangladesh.

Another recent idea for monitoring and later perhaps better controlling global migratory flows is that of the Berne Initiative (BI); Through a cooperation between States (with capital letter) with different interests, the BI would create a broad policy framework for "planning and managing the movement of people in a humane and orderly way" (The Berne Initiative 2003). By now, this, under IOM umbrella operating Swiss government -lead process is arranging discussions and meetings concerning all aspects of global migration, participated by scholars, officials and NGOs alike. Even this is a promising development, particularly binding together a global state approach of asylum and labor migration. However, the focal point, hardly to be solved in any single discussion forum, is the dilemma of contradictory state interests, combined with probably the often mutually exclusive, third interests of the individual. Which aspects will be prioritized, in which proportion, and with what kind of a consensus; universal equality, maximal economic output, sending country development or individual success? Presumably, state interests, both those of the sending and the receiving country would be focused on, undermining the individual drivers for success. In the worst case, this might halt the individuals' willingness and ability to migrate.

A similar question will be asked from the Global Commission on International Migration (GCIM). In 2003 established to consult under the mandate of U.N. Secretary General Kofi Annan, this Commission is pursuing to set international migration to the global agenda through the cooperation of the interstate and state actors, added with NGOs, media, corporate sector, migrant associations and individuals. Through enhanced information exchange, international migration shall be looked also in the context of economic development, labor supply and demand, demography, remittances, trade, poverty alleviation, integration and citizenship, social support systems, gender, human rights, public health, transnational organized crime, and overall human, national and international security. The resulting GCIM information and recommendations to the 
UN Secretary-General and other "stakeholders" shall include suggestions of how to strengthen national, regional and global governance of international migration; inter alia, how to enhance the positive potential of migration, limit its negative effects and improve the conditions of the individual migrant (Global Commission on International Migration 2003).

The GCIM is seemingly taking the individual more into consideration than the BI. Among other positive aspects, functioning directly under Kofi Annan gives the recommendations more normative authority, although it is known, that today, decisionmaking within the UN, and the de facto, effective carrying out of UN-induced decisions is a difficult mission. And although this is already a real consultative structure - further elaborated than Bhagawati's WMO - the GCIM does, as the BI, sooner or later collide with the hybrid of interests; it is certainly worthwhile to include the corporate sector and migrant associations, for more sustainable results, but tightly including these will simultaneously exponentially increase the amount of mutually hard-to-fit interests. A GCIM-based agenda would probably take so many of the mutually exclusive individualsending country-destination country interest into consideration, that finally, little will change, without consensus.

To sum up, the WMO idea and the already partly materialized, more consultative, guidelining BI and GCIM, the key question is a) how to find a consensus, even only on the recommendation level and b) how to effectively materialize any proposals. As international migration is already ontologically a highly interdisciplinary subject - added with the mutually exclusive and diverse level interests of the actors - very skilful diplomacy lead by some high-profile figure is needed, at least in the initial phase. Simultaneously, the positive aspects of international migration should be carefully surveyed and effectively made public in the global media. With a key figure in lead, and with a plenty of well founded, widely public information about the benefits of global migration, a sufficiently strong WMO might be considered.

\section{Conclusions}

In this article, I have departed from the point that international migration of the educated is an ever increasing, per se healthy and beneficial phenomenon, for the individual and for the sending and host countries alike. As such, the international movement of the educated should not be halted by any grossly restrictive measure. By this I do not mean that states should not have sovereignty in choosing the voluntary labor migrants they need. Quite the contrary, only a careful charting of domestic needs and a credible immigrant selection system corresponding to such needs is a prerequisite for the immigrant succeeding in and being beneficial for the host country. 
With the principle of free international movement of labor I rather mean that departure from the sending country should be free, and simultaneously, the monitoring, control and possible elimination of problems induced by such departure should be in the responsibility of the whole global community, and particularly that of all the recruiting countries in compus.

Why is such global responsibility growing in importance in today's international migration? As indicated above, the current trend of international labor migration - the developed immigration countries deliberately fascinating the educated elite from the developing world, with families for permanent stay and integration - is creating challenges for the sending country, as we are simultaneously determined to persist to the free nature of global labor migration.

As evidenced, the educated migrant creates acute problems for the sending country, if many emigrate at the same time. Even more importantly, the educated emigrant is less likely to return or to send remittances back home. In addition to through the remaining sending country lack of economic progress, the propensity of return is lessened through all the factors that the recruiting country such as Canada and New Zealand is pursuing with modern immigration policies; education, long stay, family included and good integration. Precisely these same four factors are playing as concerns the propensity to remit money back home.

Still, remittances do account for a vast amount of money, and many countries such as Egypt, Mexico and the islands in the Caribbean are downright dependent on the remittance flows. This dependency brings us to another problem, however; In case of no remittances, brain drain may be fatal to e.g. a Sub-Saharan country with a heavy outflow of doctors, whereas in case of existing remittances, actual human resource- and innovation-induced development may halt, and sluggishness and excessive international dependency may also result. There is scarce evidence that remittances would actually decrease poverty and income gaps on the macro level.

In sum, an international structure is needed, to discourage excessive brain drain, to support countries already suffering from brain drain, to increase the destination country awareness of the consequences of brain drain, and to facilitate the smooth flow and macro-economically constructive use of remittances.

Today, there are already international structures to monitor and to give guidelines even for a comprehensive control of international migration. Related to the sending country developmental aspects focused in the first part of this article, they do take these developmental questions into consideration, but much is to be done. Either too many actors or too many interests are considered, to give all the actors equal chances. 
As of March 2004, the temporary, UN-driven GCIM has encouragingly included the well-being of the individual high on its mandate, and will also call individuals to its consultations. In the very complex fora of international labor migration, the needs of the individual do of course not alone suffice, for creating a satisfactory global WMO structure suggested by Bhagawati, but the well-being of the individual is ethically and even practically a very sustainable starting point. In an ideal society, state interests should ultimately follow the ones of the individual, be it the majority representative or the immigrant.

Practically, an individual-based international structure for monitoring and perhaps controlling global migration - if skillfully established and carefully operated - is also the most likely to bring about sustainable results. Looking excessively at the state - as the primary and foremost actor - may more easily cause individual opposition, as then, there may be a tendency to observe individuals as mere bulk commodities, movable based on the contemporary needs of the states. Still, the states have to be tightly included, despite increasing globalization; as of today, states still have best knowledge of and control on the aspects of borders, citizenship and economic growth. Interstate cooperation is currently the only existing - although not always very effective - way of cooperating on global matters.

In case of no global agreement or structure, it is evident, that the third world will carry the burden, and in the developing countries, particularly the poor individual will suffer. If long-standing and wide, such development may lead to broader conflicts.

In conclusion, international voluntary migration of the educated workforce is an ever increasing phenomenon that will have to do with exponentially growing amounts of people, through increasing networking. This is undoubtedly one of the major global questions of tomorrow, not only from the angle of the individual, but also from that of the states and the whole global community. Leaving the questions of ethics and fairness in international labor migration unanswered today may bring short-sighted advantage and pleasure for the developed world now, but may gradually, through uncompensated brain drain cause massive, systematic income gaps and regional problems in the developing world. Without strong efforts now, the trend in the health and education sectors in Sub-Saharan Africa today may be a trend of whole Africa, Asia and Latin America tomorrow. At worst, brain drain may turn to regional conflicts and there through to a lavine of another form of migration, namely asylum. 


\section{References}

Adams, Richard H. 2003. International Migration, Remittances and the Brain Drain: A Study of 24 Labour-Exporting Countries. Washington:World Bank.

All Africa, 18.2.2004.

Asia Africa Intelligence Wire, 16.2.2002.

Beine, Michel, Frederic Docquier and Hillel Rapoport. 2003. Brain Drain and LDC's Growth: Winners and Losers. IZA Discussion paper series No. 819. Bonn.

Bhagwati, Jagdish. 2003. Managing Migration. Foreign Affairs January/February 2003.

Black, Richard, Soaring Remittances Raise New Issues, available at http://www.migrationinformation.org/Feature/display.cfm?ID=127. [cited 17 June 2005].

Borjas, George J. 2000. Labor Economics. Boston: McGraw Hill.

Brettell, Caroline B. and James F. Hollifield. 2000. Migration Theory - Talking Accross Disciplines. New York: Routledge

Carrington, William J. and Detragiache, Enrica. 1998. How Big Is the Brain Drain? International Monetary Fund.

Constant, Amalie and Massey, D.S. 2002. Return Migration by German Guestworkers: Neoclassical versus New Economic Theories. International Migration 40(4):5-38.

Chiswick, Barry. 2000. Are Immigrants Favorably Self-Selected? An Economic Analysis. In: Migration Theory - Talking Accross Disciplines, edited by Caroline B. Brettell and James F. Hollifield. New York: Routledge.

Cornelius, Wayne A., Philip L. Martin and James F. Hollifield (editor). 1994. Controlling Immigration - A Global Perspective. Stanford, 1994.

DeVoretz, Don J. and Samuel A. Laryea. 1999. Canada Immigration Experience: Any Lessons for Europe. IZA Discussion Paper Series, No. 59, September 1999.

Emeagwali, Philip, interview, available at http://emeagwali.info/interviews/brain-drain/education-in-africa-brain-drain-problem-worldnet-africa-journal.html. [cited 17 June 2005].

Factiva/Reuters, 21.11.2003.

Faini, Riccardo. 2003. The brain drain - An unmitigated blessing? Italian Ministry of Economy. Rome.

Ghosh, Bimal. 2000. Manging Migration - Time for a New International Regime. Oxford: Oxford University Press.

Glytsos, Nicholas, P. 2002. The Role of Migrant Remittances in Development: Evidence from Mediterranean Countries. International Migration 40(1):5-26.

Green, Alan G. and David A. Green. 1996. The Economic Goals of Canada's Immigration Policy, Past and Present. Available at: http://www.econ.ubc.ca/dp9618gr.pdf [cited 17 June 2005].

Hawkins, Freda. 1991. Critical Years in Immigration - Canada and Australia Compared. Montreal: McGill-Queen's University Press.

Kwok, V. and H. Leland. 1982. An economic model of the brain drain. American Economic Review, 72, 1982.

Lowell, B. Lindsay and Rodolfo O. De La Garza. 2000. The Developmental Role of Remittances in U.S. Latino Communities and In Latin American Countries. Washington: Georgetown University. 
Obadina, Tunde. 2003. The Brain Drain as a Source of Revenue, available at http://allafrica.com/stories/200309180203.html. [cited 20 June 2005].

Oderth, Reidar. 2002. Migration and Brain Drain - The Case of Malawi. New York: WCP.

OECD SOPEMI 2002. Trends In International Migration. Paris.

O’Neil, Kevin. 2003. Using Remittances and Circular Migration to Drive Development, Migration Policy Institute, available at http://www.migrationinformation.org/feature/display.cfm?ID=133.

Oyowe, Augustine. 1996. Colossal loss of investment for developing countries. The Courier ACP- EU. No. 159, September-October 1996.

Pakistan \& Gulf Economist, 3.8.2003.

PANA Daily Newswire, 22.9.2003.

Poot, Jacques. 1992. International Migration in the New Zealand Economy of the 1980s. In: New Zealand and International Migration: A Digest and Bibliography No. 2, edited by A.D. Trlin and P. Spoonley, pp. 29-47. Department of Sociology, Massey University, Palmerston North.

Regional Surveys of the World, The Far East and Australasia 2002. London: Europa Publications.

Rudolph, Christopher. 1998. Globalization, sovereignty and migration: A conceptual framework. UCLA Journal of International Law and Foreign Affairs 3(2).

Sander, Cerstin. 2003. Migrant Remittances to Developing Countries. UK Department of International Development.

South China Morning Post, 17.2.2004.

Stalker, Peter. 1994. The Work of Strangers - A Survey of International Labour Migration. ILO. Geneva.

. Stalker Peter. Stalker's guide to international migration. Available at http://pstalker.com/migration/mg_emig_4.htm

Tanner, Arno. 2003. Siirtolaisuus, valtio ja politiikka - Kanadan, Sveitsin ja Uuden-Seelannin työvoiman maahanmuutto ja politiikka 1975-2001. [Migration, policy and the state - labor immigration and policy in Canada, New Zealand and Switzerland 1975-2001] Helsinki: Directorate of Immigration and Ministry of Labor.

The Berne Initiative. 2003. The Goal of the Berne Initiative. Berne.

The Independent, 17.7.2001.

Trlin, Andrew D. ja Paul Spoonley (ed.). 1992. New Zealand and International Migration - A

Digest and Bibliography number 2. Palmerston North: Massey University. . 1997. New Zealand And International Migration - A Digest and Bibliography, number

3. Palmerston North: Massey University.

UNHCR. Asylum levels and Trends: Europe and non-European Industrialized Countries, 2003, 24.2.2004.

United Nations. 2002. Number of World's Migrants Reaches 175 Million Mark - Migrant Population Has Doubled in Twenty-Five Years. UN Press Release POP/844, 28.10.2002.

Zelinsky, Wilbur. 1971.The Hypothesis of the Mobility Transition. Geographic Review (61):219-249. 